\title{
Proses Pembakaran Pirolisis dengan Jenis Biomassa dan Karakteristik Asap Cair yang Dihasilkan
}

\author{
Kemas Ridhuan', Dwi Irawan², Rizki Inthifawzi ${ }^{3}$ \\ Program Studi Teknik Mesin, Fakultas Teknik, Universitas Muhammadiyah Metro \\ JI. Ki Hajar Dewantara 15 A Metro, Lampung, Indonesia \\ Email: kmsridhuan@yahoo.co.id ${ }^{1}$, dwi_irawan12@yahoo.co.id ${ }^{2}$, rizky52@yahoo.com³
}

\begin{abstract}
Abstrak
Biomassa merupakan satu-satunya sumber karbon yang dapat diperbaharui dan mampu diproses menjadi bahan bakar yang berupa gas, cair, dan padat yang baik. Biomassa juga dapat diolah menjadi bahan pengawet makanan karena mengandung senyawa-senyawa antibakteri dan antioksidan dalam bentuk cairan atau asap cair. Untuk mendapatkan hasil asap cair yang sesuai dan memadai dengan peruntukannya maka perlu diolah dengan menggunakan berbagai jenis jenis biomassa yang diproses pada pembakaran pirolisis. Dengan pembakaran pirolisis biomassa terdekomposisi termokimia dengan pemanasan menjadi gas kemudian didinginkan dikondensor dan menjadi cairan atau asap cair. Tujuan penelitian ini adalah untuk mengetahui jumlah asap cair yang dihasilkan dari jenis biomassa baku kulit kelapa muda, bambu dan kulit durian dengan karaktristik asap cairnya yang dibakar secara pirolisis. Penelitian ini dilakukan di laboratorim Teknik Mesin Universitas Muhammadiyah Metro, penelitian ini menggunakan reaktor pirolisis, retot dan kondensor dengan bahan bakar dan bahan baku biomassa yang sama yaitu kulit kelapa muda bahan bakar $13 \mathrm{~kg}$ dan bahan baku $3 \mathrm{~kg}$, bahan bakar bambu sebesar $13 \mathrm{~kg}$ dan bahan baku $3 \mathrm{~kg}$, bahan bakar kulit durian sebesar $8 \mathrm{~kg}$ dan bahan baku $1,2 \mathrm{~kg}$. Hasil penelitian yang didapat yaitu kulit kelapa muda menghasilkan asap cair $100 \mathrm{ml}$ dengan karakteristiknya yaitu $\mathrm{pH}$ 0.596, viskositas $1.780 \mathrm{CPs}$ dan densitas $0,343 \mathrm{~g} / \mathrm{cm}^{3}$ lalu bambu menghasilkan asap cair 120 $\mathrm{ml}$ dengan karakteristiknya yaitu $\mathrm{pH}$ 0.707, viskositas 2.626 CPs dan nilai kalori 1983,950 $\mathrm{Cal} / \mathrm{g}$, densitas $0,427 \mathrm{~g} / \mathrm{cm}^{3}$ dan kulit durian menghasilkan asap cair $74 \mathrm{ml}$ dengan karakteristiknya yaitu $\mathrm{pH}$ 0.676, viskositas $1.574 \mathrm{Cps}$ dan nilai kalori 2177,464 Cal/g, densitas $0,271 \mathrm{~g} / \mathrm{cm}^{3}$
\end{abstract}

Kata kunci: Pembakaran, Pirolisis, asap cair, biomassa.

\section{Pendahuluan}

Pembakaran adalah suatu runutan reaksi kimia antara suatu bahan bakar dan suatu oksidan, disertai dengan produksi panas yang kadang disertai cahaya dalam bentuk pendar atau api. Dalam suatu reaksi pembakaran lengkap, suatu senyawa bereaksi dengan zat pengoksidasi, dan produknya adalah senyawa dari tiap elemen dalam bahan bahan bakar dengan zat pengoksidasi. Pembakaran pirolisis merupakan suatu proses dekomposisi termokimia yang terjadi bahan organik (biomasa) melalui proses pemanasan dengan menggunakan sedikit atau tanpa oksigen dimana material mentah akan mengalami pemecahan struktur kimia menjadi fase gas.

Pada proses pembakaran pirolisis terdapat beberapa fase yaitu fase pengeringan; terjadi pada suhu $200^{\circ} \mathrm{C}$. Fase pirolisis pada suhu $200-500^{\circ} \mathrm{C}$, dan fase evolusi gas: terjadi pada suhu 500$200^{\circ}$ C. Berdasarkan Setiawan [1], karakteristik pirolisis campuran menampilkan 3 macam grafik karakteristik pirolisis, yaitu massa, laju penurunan massa dan temperatur. Tahap yang pertama adalah pengeringan yang ditandai dengan penurunan massa yang berjalan secara lambat. Tahap kedua adalah devolatilisasi yang ditandai dengan penurunan massa yang sangat cepat. Tahap 
ketiga adalah karbonasi yang ditandai penurunan massa yang kembali melambat [1].

Pembakaran pirolisis dapat menghasilkan produk utama yang berupa arang (char), asap cair (bio-oil) dan gas. Arang yang dihasilkan merupakan bahan bakar bernilai kalori yang tinggi ataupun digunakan sebagai karbon aktif. Asap cair yang dihasilkan dapat digunakan sebagai zat additive atau bahan pengawet makanan atau produk tertentu. Sedangkan gas yang terbentuk dapat dibakar secara langsung. Gas dari pirolisis dapat dibedakan menjadi gas yang tidak dapat dikondensasi $(\mathrm{CO}$, $\mathrm{CO}_{2}, \mathrm{CH}_{4}$, dll) dan gas yang dapat dikondensasi (tar). Minyak akan terjadi pada proses kondensasi dari gas yang terbentuk, disebut juga asap cair.

Menurut Yaman [2], proses pembuatan asap cair melalui proses pirolisis dan destilasi. Pirolisis adalah proses pemanasan suatu zat dengan oksigen terbatas sehingga terjadi penguraian komponen-komponen penyusun kayu keras. Pada proses pirolisis energi panas mendorong terjadinya oksidasi sehingga molekul karbon yang kompleks terurai sebagian besar menjadi karbon atau arang. Dan distilasi adalah suatu cara pemisahan larutan dengan menggunakan panas sebagai pemisah atau separating agent [2].

Pembakaran pirolisis menggunakan berbagai biomassa yang berasal dari beberapa jenis sumber tumbuhan. Biomassa adalah material biologis yang berasal dari suatu kehidupan, atau organisme yang masih hidup yang berstruktur karbon dan campuran kimiawi bahan organik yang mengandung hidrogen, nitrogen, oksigen, dan sejumlah kecil dari atom-atom \& elemen-elemen lainnya. Setiap biomassa memiliki karaktristik dan komposisi bebeda-beda tergantung dari jenisnya dan bentuknya. Seperti biomassa jenis sekam padi memiliki ukuran butiran kecil dengan tekstur sedikit keras dan kadar air sedikit. Kemudian bambu dengan tekstur keras, panjang, dan sedikit air. Kemudian kulit durian dengan bijian besar, lunak, kandungan air tinggi. Pada pembakaran pirolisis akan menghasilkan produk asap cair yang berbeda pula. Menurut Guillen, asap cair yang berasal dari bahan baku yang berbeda akan menghasilkan komponen kimia yang berbeda [3].

Asap cair adalah bahan cairan yang berwarna kehitaman yang berasal dari biomassa seperti kayu, kulit kayu dan biomassa lainnya seperti dari limbah kehutanan dan industri hasil hutan melalui proses pirolisis. Mengandung karbon, hidrogen, dan oksigen. Kandungan asam organik dalam asap cair adalah air, tetapi air tidak bersifat kontaminan seperti pada petroleum, karena air bercampur dengan asap cair.

Asap cair merupakan suatu hasil kondensasi atau pengembunan dari uap hasil pembakaran secara langsung maupun tidak langsung dari bahan-bahan yang banyak mengandung lignin, selulosa, hemiselulosa serta senyawa karbon lainnya. Asap cair bisa juga berarti hasil pendinginan dan pencairan asap dari tempurung kelapa yang dibakar dalam tabung tertutup. Asap yang semula partikel padat didinginkan dan kemudian menjadi cair itu disebut dengan nama asap cair. Asap cair biasanya digunakan sebagai bahan bakar atau juga sebagai pengawet makanan atau produk tertentu.

Menurut Kamulyan [4], liquid smoke atau lebih dikenal sebagai asap cair merupakan suatu hasil destilasi atau pengembunan dari uap hasil pembakaran tidak langsung maupun langsung dari bahan bahan yang banyak mengandung karbon serta senyawa-senyawa lain. Bahan baku yang banyak digunakan sekarang ini adalah kayu, bongkol kelapa sawit, dan ampas hasil penggergajian kayu [4].

Berdasarkan Harinen [5], cara yang paling umum untuk menghasilkan asap pada proses pengasapan makanan adalah dengan membakar serbuk gergaji kayu keras dalam satu tempat yag disebut alat 
pembangkit asap, kemudian asap tersebut dialirkan ke rumah asap dalam kondisi sirkulasi udara dan temperatur yang terkontrol. Produksi asap cair merupakan hasil pembakaran tidak sempurna yang mengakibatkan reaksi dekomposisi karena pengaruh panas, kondensasi, dan polimerisasi [5].

Untuk mendapatkan hasil asap cair yang optimum maka sangat tergantung pada kondisi dan proses kondensasi yang terjadi, semakin rendah suhu air kondensor, semakin banyak minyak yang dihasilkan. Dengan suhu air kondensor $20^{\circ} \mathrm{C}$ hasilkan minyak $50 \%$ lebih banyak dari pada dengan suhu air kondensor natural $\left(29-30^{\circ} \mathrm{C}\right)$. Suhu air kondensor memiliki sedikit pengaruh terhadap kinerja reaktor dalam mencapai suhu tertentu.

Dalam perkembangan konversi biomassa menjadi bahan bakar, proses kimia termal lebih banyak digunakan dibandingkan dengan proses biokimia. Hal ini disebabkan waktu proses secara termal lebih singkat dibandingkan dengan proses biokimia dan juga efisiensi konversi yang pada umumnya diperoleh dari proses termal lebih baik, yaitu antara $60 \%$ sampai dengan $80 \%$.

Proses konservasi energi diupayakan dengan ditemukan suatu energi pengganti yang dapat diperoleh dari sumber-sumber atau bahan-bahan yang siklus pembaharuannya tidak memerlukan waktu yang terlalu lama yang disebut sebagai energi alternatif.

\section{Tinjauan Pustaka}

\section{Biomassa}

Biomassa adalah bahan biologis yang berasal dari organisme atau makhluk hidup yang tergolong megandung lignin dan selulosa dan holoselulosa. Biomassa dapat diperoleh dari tanaman perkebunan atau pertanian, hutan, peternakan, bahkan sampah. Biomassa adalah bahan-bahan organik berumur relatif muda yang berasal dari tumbuhan atau hewan, baik yang terbentuk dari hasil produksinya, sisa metabolismenya, ataupun limbah yang dihasilkan. Biomassa merupakan satusatunya sumber karbon yang dapat diperbaharui dan mampu diproses menjadi bahan bakar gas, cair, dan padat yang baik.

Energi biomassa menjadi salah satu sumber energi alteratif pengganti bahan bakar fosil (minyak bumi), karena beberapa sifatnya yang menguntungkan yaitu, dapat dimanfaatkan secara lestari karena sifatnya yang dapat diperbaharui (renewable resources), relatif tidak mengandung unsur sulfur sehingga tidak menyebabkan polusi udara dan juga dapat meningkatkan efisiensi pemanfaatan sumber daya hutan dan pertanian.

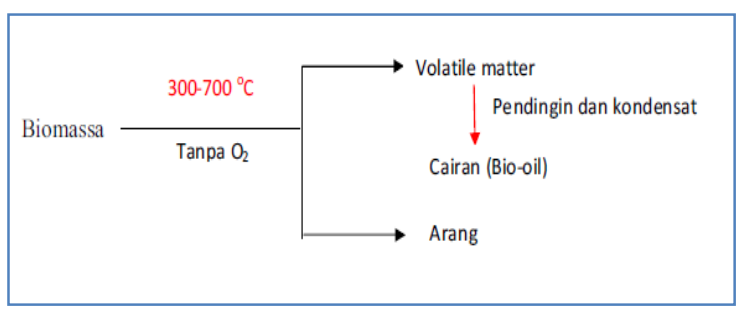

Gambar 1. Skema pengolahan biomassa

\section{Kulit Durian}

Durian merupakan salah satu buah yang cukup populer di Indonesia, karena aromanya yang khas. Durian berasal dari wilayah Asia Tenggara. Karakteristik dari buah durian yaitu bentuknya besar bulat atau oval, baunya beraroma khas, kulit buah yang keras dan tebal, kulit buahnya berlekuk-lekuk tajam sehingga menyerupai duri. Kulit durian mengalami proses degradasi atau pembusukan yang lama, dikarenakan kandungan selulosa yang tinggi. Menurut Hatta, kulit durian memiliki kandungan selulosa yang tinggi sebanyak 50-60\% dan lignin serta kandungan pati yang rendah masingmasing sebanyak 5\%, sehingga proses pendegradasiannya lama [6]. Hal tersebut diperkuat dengan penelitian Anindyawati, yang menyatakan bahwa kulit buah merupakan limbah sisa hasil pertanian dan mengandung lignoselulosa yang kompleks, sehingga perlu adanya proses perlakuan awal untuk mempermudah proses hidrolisis [7]. 


\section{Bambu}

Bambu adalah tanaman jenis rumput-rumputan dengan rongga dan ruas di batangnya, bambu memiliki berbagai macam. Bambu sebagai bahan baku industri tekstil yang eco-friendly memiliki beberapa keunggulan, yakni sangat cepat tumbuh dan mengandung senyawa antimikrobial. Serat bambu merupakan bahan yang digunakan sebagai bahan baku industri tekstil [8]. Bambu merupakan salah satu tanaman dengan pertumbuhan paling cepat, dalam sehari bambu dapat tumbuh sepanjang $60 \mathrm{~cm}$ (24 inchi) bahkan lebih tergantung pada tanah atau tempat dimana bambu ditanam. komposisi kimia bambu secara umum sama dengan kayu daun lebar kecuali ekstrak alkalin, abu, dan kadar silika yang tinggi. Banyak hubungan diantara komposisi kimia dan penggunaannya. Menurut Suparno [9], karakteristik kimia batang bambu terdiri atas $64,43 \%$ holoselulosa, selulosa $43,27 \%$, hemiselulosa $21,16 \%$, Lignin klason $24,33 \%$ dan zat ektsraktif $4,12 \%$.

\section{Kulit Kelapa Muda}

Kelapa (cocos nucifera) merupakan anggota tunggal dari marga cocos yang berasal dari satu jenis tumbuhan dari suku aren-arenan (arecaceae) atau palempaleman (palmae). Kelapa memiliki banyak manfaat atau serba guna, karena hampir semua bagian kelapa bisa diolah atau dimanfaatkan khususnya bagi masyarakat pesisir. Karakteristik dari kelapa yaitu buahnya besar, berdiameter 10 sampai $20 \mathrm{~cm}$ atau lebih, berwarna kuning, hijau atau coklat, buah tersusun dari mesokarp berbentuk serat yang berlignin (sabut), dan endokarp yang keras (batok). Berdasarkan Pugersari [10], berat dan tebal tempurung sangat ditentukan oleh jenis tanaman kelapa. Berat tempurung sekitar $15-19 \%$ bobot total buah kelapa dengan ketebalan 3-5 mm. Tempurung kelapa termasuk golongan kayu keras, secara kimiawi memiliki komposisi kimiawi yang hampir mirip dengan kayu yaitu tersusun dari lignin
$36,51 \%$, Selulosa 33,61\%, Semiselulosa $29,27 \%$.

\section{Pirolisis}

Pirolisis adalah dekomposisi bahan kimia organik melalui proses pemanasan tanpa atau sedikit oksigen atau reagen lainnya. Dimana material mentah akan mengalami pemecahan struktur kimia menjadi gas. Pirolisis adalah kasus khusus dari thermolysis terkait dengan proses kimia charring dan yang paling sering digunakan yaitu bahan organik.

Proses pirolisis dikategorikan menjadi 4 tipe yaitu:

1. Pirolisis lambat (slow pyrolysis). Pirolisis yang dilakukan pada pemanasan rata-rata lambat (5-7 $\mathrm{K} / \mathrm{menit}$ ). Pirolisis ini menghasilkan cairan yang sedikit sedangkan gas dan arang lebih banyak dihasilkan.

2. Pirolisis cepat (fast pyrolysis). Pirolisis ini dilakukan pada lama pemanasan 0,5-2 detik, suhu 400-600 ${ }^{\circ} \mathrm{C}$ dan proses pemadaman yang cepat pada akhir proses. Pemadaman yang cepat sangat penting untuk memperoleh produk dengan berat molekul tinggi sebelum akhirnya terkonversi menjadi senyawa gas yang memiliki berat molekul rendah. Dengan cara ini dapat dihasilkan produk minyak pirolisis yang hingga $75 \%$ lebih tinggi dibandingkan dengan pirolisis konvensional.

3. Pirolisis Kilat (flash pyrolysis). Proses pirolisis ini berlangsung hanya beberapa detik saja dengan pemanasan yang sangat tinggi. Flash pyrolysis pada biomassa membutuhkan pemanasan yang cepat dan ukuran partikel yang kecil sekitar 105 - 250 $\mu \mathrm{m}$.

4. Pirolisis katalitik biomassa. Pirolisis ini untuk membuktikan kualitas minyak yang dihasilkan. Minyak tersebut diperoleh dengan cara pirolisis katalitik biomassa tidak memerlukan teknik pra-pengolahan sampel yang mahal yang melibatkan kondensasi dan penguapan kembali. 


\section{Asap Cair}

Asap merupakan suatu sistem kompleks yang terdiri dari fase cairan terdispersi dan medium gas sebagai pendispersinya. Asap cair adalah suatu campuran larutan dan dispersi koloid yang berasal dari uap asap kayu dalam air yang diperoleh dari proses pirolisis kayu atau dibuat dari campuran senyawa murni.

Menurut Kilinc and Cakh [11], asap cair saat ini mulai populer digunakan sebagai bahan pengawet untuk berbagai produk pangan dan juga biopestisida untuk meningkatkan produksi pertanian. Kemudian Isamu [12], mengatakan salah satu penelitian yang sering dilakukan ialah untuk pengawetan ikan tuna dengan cara pengasapan. Asap cair yang dihasilkan pada proses pirolisis janjang dan tempurung kelapa dapat digunakan sebagai bahan pengawet, insektisida, dan obatobatan yang memberi manfaat cukup besar bagi kehidupan manusia.

Asap cair diperoleh dari pembakaran bahan yang banyak mengandung selulosa, hemiselulosa, dan lignin menghasilkan senyawa fenol, senyawa asam dan turunannya. Bahan baku yang dapat digunakan untuk menghasilkan asap cair antara lain tempurung dan serabut kelapa, sampah organik, cangkang kopi, bambu maupun merang padi. Sifat dari asap cair dipengaruhi oleh komponen utama yaitu selulosa, hemiselulosa, dan lignin yang proporsinya bervariasi tergantung pada jenis bahan yang akan di pirolisis.

\section{Metode Penelitian}

\section{Bahan}

Bahan biomassa yang digunakan adalah biomassa bambu dan biomassa kulit durian. Bambu dipotong kecil seukuran lebar $2 \mathrm{~cm}$ panjang $15 \mathrm{~cm}$ sebanyak $3 \mathrm{~kg}$ dengan bahan bakar $13 \mathrm{~kg}$ dan kulit durian satu bagian sisi dipotong dua sebanyak 1,2 $\mathrm{kg}$ dengan bahan bakar $8 \mathrm{~kg}$. Kulit kelapa muda satu bagian dipotong enam sebanyak $3 \mathrm{~kg}$ dengan bahan bakar $13 \mathrm{~kg}$. Bahan bakar kayu yang digunakan sebanyak 12 $\mathrm{kg}$.

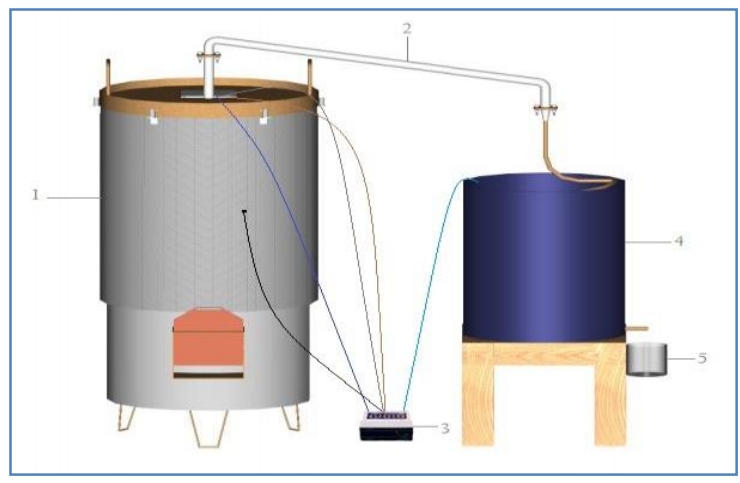

Gambar 2. Sistem rangkaian reaktor pirolisis dan kondensornya

Alat

1. Satu unit reaktor pirolisis

2. Satu unit silinder retor

3. Satu unit kondensor

4. Termokopel

Pengujian Pirolisis

1. Siapkan alat dan bahan,

2. Masukan potongan bambu ke dalam retot secara penuh lalu ditutup,

3. Masukan retot kedalam reaktor,

4. Masukan bahan bakar biomassa ke dalam reaktor secara merata dan cukup penuh,

5. Nyalakan bahan bakar dengan minyak tanah lalu ditutup,

6. Catat waktu berjalan dan suhu ditiap titik pengukuran,

7. Pada pengujian ini diambil data lama waktu pembakaran pirolisis, banyaknya asap cair yang dihasilkan dan suhu tertinggi pembakaran pirolisis di pitot,

8. Perhatikan tetesan asap cair yang terjadi,

9. Jika pengujian telah selesai, ambil asap cair yang didapat lalu diukur volumenya,

10. Lakukan pengujian dengan cara yang sama pada bahan biomassa lainnya kulit durian dan kulit kelapa muda.

Pengujian Komposisi Kimia

Asap cair yang didapat diuji karaktristik unsur kimia di laboratorium kimia untuk mengetahui kandungan dan komposisi kimia yang dimilikinya. 


\section{Hasil dan Pembahasan}

Setelah dilakukan pengujian maka didapat beberapa data dari hasil pembakaran pirolisis tersebut dengan menggunakan 3 biomassa yaitu kulit kelapa muda, bambu, dan kulit durian.

Ada tiga bagian titik suhu yang diukur yaitu suhu pembakaran di retot (bahan baku), suhu reactor (bahan bakar) dan suhu air di kondensor.

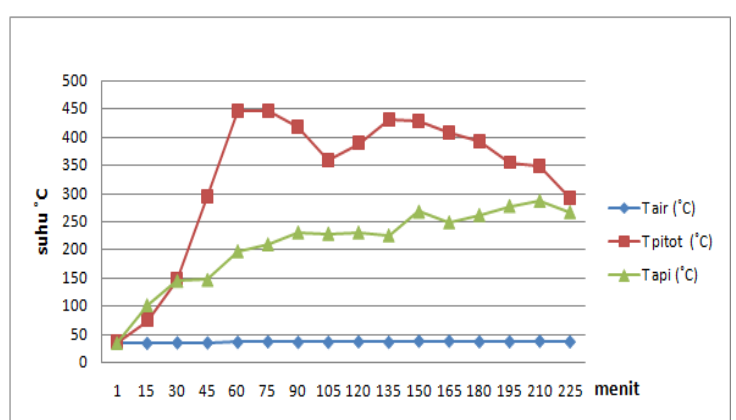

Gambar 3. Grafik perbandingan waktu dan suhu biomassa kelapa muda

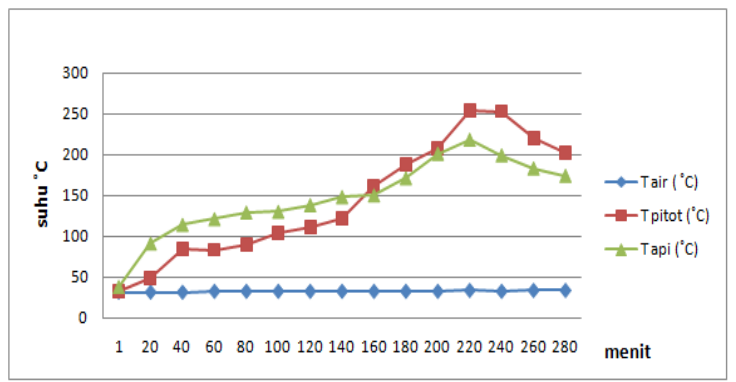

Gambar 4. Grafik perbandingan waktu dan suhu biomassa bambu tiap titik

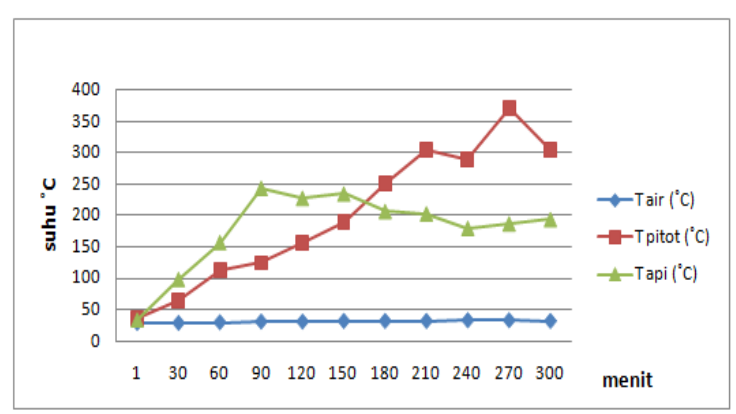

Gambar 5. Grafik perbandingan waktu dan suhu biomassa kulit durian tiap titik

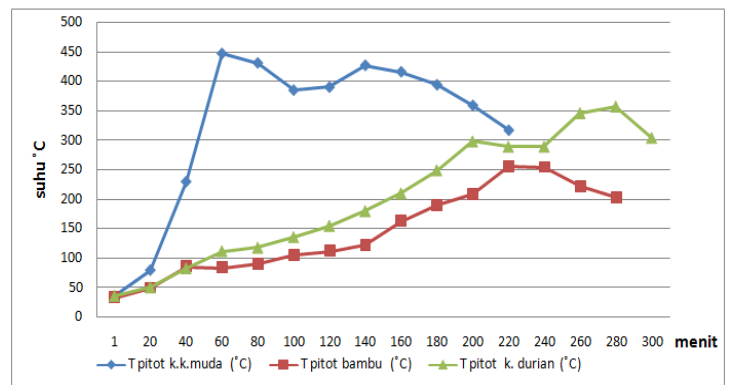

Gambar 6. Grafik perbandingan waktu dan suhu pada tiap biomassa

Pada gambar 3, 4 dan 5 terlihat bahwa suhu pembakaran pada retot cendrung lebih besar dibanding suhu pembakaran pada reaktor hal ini dikarenakan retot selain menghasilkan panas sendiri akibat pembakaran dari bahan baku biomassanya juga menerima panas dari reaktor akibat pembakaran bahan bakar biomassanya sehingga suhu retot terakumulasi dan suhunya menjadi lebih tinggi. Selain itu juga volume pitot lebih kecil dibanding volume reaktor sehingga memungkinkan pembakaran yang terjadi pada pitot menghasilkan suhu yang lebih tinggi dibandingkan suhu pada reaktor.

Pada gambar 6, terlihat perbandingan pembakaran pirolisis dari tiga bahan biomassa diketahui bahwa kulit kelapa muda menghasilkan suhu pembakaran yang lebih tinggi dibanding biomassa yang lainnya, hal ini dikarenakan bahwa dengan tekstur berserat dan lembut menyebabkan pembakaran lebih mudah terjadi sehingga suhu awal terjadinya dekomposisi termal terjadi lebih cepat, hal tersebut diperkuat dengan satu kenyataan bahwa kulit kelapa muda mengalami proses dekomposisi termal yang lebih cepat seperti terlihat dalam gambar 6.

Pada menit ke 30 terlihat kenaikan suhu yang signifikan yaitu $150^{\circ} \mathrm{C}$ pada kulit kelapa muda dibanding dengan bahan biomassa lainnya hanya $60^{\circ} \mathrm{C}$ dan $75^{\circ} \mathrm{C}$. Hal tersebut diduga karena perbedaan konduktivitas termal sampel biomassa disamping dapat juga disebabkan karena perbedaan kadar air biomassa yang harus 
diuapkan dalam proses pirolisis. Selain itu juga diduga karena kandungan volatile mater dari kulit kelapa muda lebih besar bila dibandingkan dengan biomassa lainnya. Berdasarkan penelitian Anggraini [13], asap cair terbentuk dari kondensasi asap melalui proses pirolisis konstituen kayu seperti selulosa, hemiselulosa, dan lignin. Dan menurut Ayudiarti [14], kualitas asap cair hasil pirolisis ini tergantung pada bahan baku (jenis kayu), suhu pirolisis, ukuran partikel kayu, dan kadar air kayu.

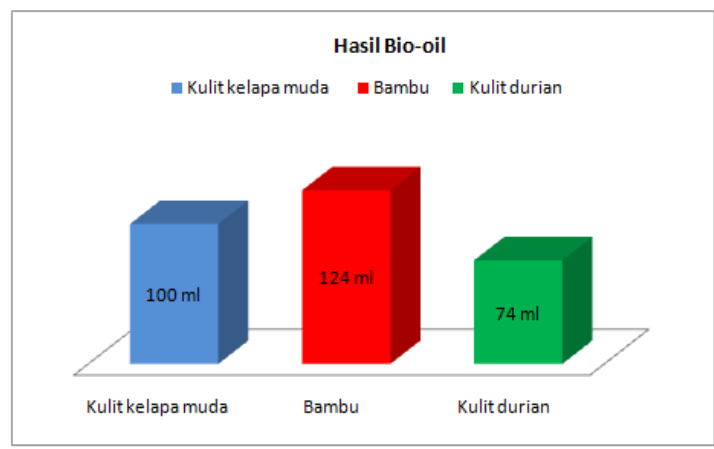

Gambar 7. Grafik hasil asap cair dari tiap biomassa

Volume asap cair yang dihasilkan seperti pada gambar 7 terlihat bahwa bambu memiliki hasil yang lebih besar yaitu $124 \mathrm{ml}$ sementara kulit kelapa muda $100 \mathrm{ml}$ dan kulit durian hanya $74 \mathrm{ml}$, hal ini dimungkinkan bahwa semakin tinggi suhu pirolisis maka jumlah asap cair yang dihasilkan semakin banyak, karena semakin tinggi suhu maka kecepatan reaksi pirolisis akan semakin meningkat sehingga kemampuan untuk menguraikan senyawa-senyawa organik yang ada pada bambu juga semakin besar. Sesuai dengan pendapat Ratnawati dan Hartanto [15], hal itu disebabkan pada suhu tinggi dan waktu yang lama dekomposisi bahan baku lebih sempurna sehingga rendemen asap cair yang dihasilkan lebih tinggi. Dan juga nilai jumlah asap cair sangat bergantung pada suhu, laju pemanasan, ukuran partikel, jenis dan komposisi dari bahan baku.

Selain itu juga dapat disebabkan dari besarnya kadar air yang dimiliki oleh biomassa tersebut yang selama pemanasan akan menguap dan mengembun kembali ke dalam kondensor sehingga volume cairan destilat yang dihasilkan akan bertambah. Kemudian juga besarnya kadar cairan destilat ini menggambarkan banyaknya kadar asam asetat dalam biomassa tersebut. Berdasarkan penelitian Yatagai [16] bahwa komponen utama yang terdapat dalam cairan destilat adalah asam asetat, asam butirat, asam crotonat, etil phenol, acetovanillon, furfural, pentan-5olide.

Hasil uji laboratorium kimia

Tabel 1. Viscositas asap cair dari biomassa

\begin{tabular}{ccccccc}
\hline No & $\begin{array}{c}\text { Kode } \\
\text { sampel }\end{array}$ & I & II & III & $\begin{array}{c}\text { Rata- } \\
\text { rata } \\
(\mathbf{t})\end{array}$ & $\begin{array}{c}\text { Viscositas } \\
(\mathbf{C P s})\end{array}$ \\
\hline 1 & Bambu & 26.06 & 26.04 & 26.21 & 26.10 & 2.626 \\
\hline \multirow{2}{*}{2} & $\begin{array}{l}\text { Kulit } \\
\text { Kelapa } \\
\text { Muda }\end{array}$ & 17.88 & 17.75 & 17.45 & 17.69 & 1.780 \\
\hline 3 & $\begin{array}{l}\text { Kuliat } \\
\text { Durian }\end{array}$ & 15.87 & 15.60 & 15.47 & 15.65 & 1.574 \\
\hline
\end{tabular}

Pada tabel 1, terlihat bahwa viskositas asap cair tertinggi pada biomassa bambu yaitu 2,626 cps dan viscositas yang kecil pada biomassa kulit durian yaitu $1,574 \mathrm{cps}$, hal ini karena semakin tinggi suhu pembakaran maka tingkat kekentalan asap cair juga meningkat. Hasil ini tidak jauh berbeda dengan penelitian Zulkania [17] yaitu viskositas dari bio-oil yang diuji memiliki kisaran nilai 1,3034 $\mathrm{cP}$ sampai 1,7821 cP. Viskositas tertinggi terjadi pada temperatur $550^{\circ} \mathrm{C}$ dengan ukuran partikel biomassa $\quad 0-30 \quad$ Mesh. Sedangkan viskositas terendah terjadi pada pirolisis pada temperatur $500^{\circ} \mathrm{C}$ dengan ukuran partikel biomassa 20+30 Mesh.

Tabel 2. Derajat keasaman asap cair dari tiap biomassa

\begin{tabular}{clccc}
\hline No & $\begin{array}{l}\text { Kode } \\
\text { sampel }\end{array}$ & $\begin{array}{c}\text { Sampel } \\
(\mathbf{g r})\end{array}$ & $\begin{array}{c}\text { Titrasi } \\
(\mathbf{m l})\end{array}$ & $\begin{array}{c}\text { Total } \\
\text { asam }\end{array}$ \\
\hline 1 & Bambu & 1.0178 & 7.2 & 0.707 \\
\hline \multirow{2}{*}{2} & $\begin{array}{l}\text { Kulit } \\
\text { Kelapa } \\
\text { Muda }\end{array}$ & 1.0571 & 6.3 & 0.596 \\
\hline 3 & Kulit durian & 1.0204 & 6.9 & 0.676 \\
\hline
\end{tabular}

Hasil pengujian tabel 2, terlihat kadar asam asap cair menunjukkan bahwa asap cair memiliki kadar asam yang lebih besar pada temperatur pembakaran yang 
lebih tinggi, yaitu pada bambu sebesar 0,707 gr/ml dibandingkan pada biomassa lainnya yang sedikit lebih kecil seperti pada kulit durian yaitu $0,676 \mathrm{gr} / \mathrm{ml}$. Hal ini disebabkan karena kadar selulosa dan hemiselulosa yang ada pada limbah kulit durian berada dalam jumlah yang sedikit karena proses pembakaran dan terkonversi menjadi asap cair.

Perbedaan kadar asam yang tidak terlalu jauh ini dikarenakan jumlah asam asetat di dalam asap cair tidak berubah terhadap waktu namun memperbesar volume produk yang dihasilkan. Perbedaan jumlah kadar asam ini dikarenakan asam organik yang dihasilkan dari dekomposisi komponen hemiselulosa berupa heksosan dan selulosa mengalami proses pirolisis lebih sempurna pada temperatur pembakaran yang lebih tinggi berupa heksosan dan selulosa mengalami proses pirolisis lebih sempurna pada temperatur pembakaran yang lebih tinggi. Hal ini sesuai dengan penelitian Zulkania [17], yaitu asam asetat terendah didapat dari pirolisa pada temperatur $500^{\circ} \mathrm{C}$ yaitu sebesar $0,432 \mathrm{mg} / \mathrm{ml}$, dan tertinggi pada temperatur $550^{\circ} \mathrm{C}$ yaitu sebesar 0,56 untuk sampel berbentuk kepingan. Keasaman yang tinggi disebabkan adanya asam asetat dan asam lainnya akibat proses pirolisis yang memecah selulosa dan lignin serta zat ekstraktif yang bersifat asam.

Tabel 3. Kerapatan asap cair dari biomassa

\begin{tabular}{llc}
\hline No. & Biomassa & $\begin{array}{c}\text { Kerapatan } \\
\left(\mathrm{gr} / \mathrm{cm}^{3}\right)\end{array}$ \\
\hline 1. & Kulit kelapa muda & 0,344 \\
2. & Bambu & 0,427 \\
3. & Kulit durian & 0,271 \\
\hline
\end{tabular}

Dari tabel 3 terlihat bahwa kerapatan asap cair dipengaruhi oleh suhu pirolisis, yaitu semakin tinggi suhu pirolisis, maka akan semakin besar pula nilai kerapatan dari asap cairnya. Terlihat bahwa asap cair dari bambu mempunyai kerapatan lebih besar dibandingkan asap cair dari kulit kelapa muda atau kulit durian. Hal ini diduga bahwa asap cair yang berasal dari pirolisis serat basah masih mengandung air yang masuk ke destilat pada awal proses. Selain itu kerapatan asap cair juga dipengaruhi oleh waktu. Bahwa semakin lama waktu pirolisis, semakin besar kerapatan asap cairnya dan destilat yang keluar pada waktu yang semakin lama telah tercampur dengan senyawa tar, karena tar terbentuk pada suhu yang tinggi. Hal ini sesuai dengan penelitian Sunarsih [18], pada suhu $150^{\circ} \mathrm{C}$ kerapatan asap cairnya $2,1084 \mathrm{gr} / \mathrm{ml}$ dan pada suhu $400^{\circ} \mathrm{C}$ kerapatannya naik menjadi 4,1192 gr/ml pada biomassa serat pati aren.

Tabel 4. Randemen asap cair dari biomassa

\begin{tabular}{llc}
\hline No. & Biomassa & $\begin{array}{c}\text { Randemen } \\
(\mathbf{\%})\end{array}$ \\
\hline 1. & Kulit kelapa muda & 3,33 \\
2. & Bambu & 4,0 \\
3. & Kulit durian & 6,17 \\
\hline
\end{tabular}

Seperti pada tabel 4, terlihat bahwa randemen asap cair tertinggi pada kulit durian yaitu $6,17 \%$ dan yang terendah pada kulit kelapa mudah yaitu 3,33\% hal ini bisa sangat bergantung pada suhu, waktu, laju pemanasan, ukuran partikel, jenis dan komposisi dari bahan biomassa. Walaupun pada suhu pirolisis yang sama. Volume asap cair yang diperoleh lebih sedikit dan hal ini berkaitan dengan desain pirolisator yang digunakan.

Kehilangan bobot (loss) adalah banyaknya bahan baku yang tidak terkonversi menjadi produk (kondensat asap). Bobot hilang juga dapat berupa gas yang tidak terkondensasi dan langsung manguap setelah melewati kondesor seperti gas $\mathrm{CO}, \mathrm{CH}_{4}, \mathrm{CO}_{2}$ dan $\mathrm{H}_{2}$ [15]. Selain itu, kehilangan bobot pada proses pirolisis ini juga dapat berupa kerak yang tertinggal pada alat pembakaran ataupun pada kondensor. Bobot hilang (loss) selama proses pirolisis pada penelitian ini berkisar antara 14,65 $\pm 0,90 \%-19,20 \pm 1,42$ $\%$ (b/b). Hasil analisis sidik ragam menunjukkan bahwa interaksi perlakuan suhu dan waktu pirolisis tidak berpengaruh nyata terhadap kehilangan bobot (loss) selama proses pirolisis, tetapi faktor 
tunggal suhu dan waktu pirolisis berpengaruh sangat nyata terhadap kehilangan bobot (loss),

\section{Kesimpulan}

Dari hasil penelitian ini maka dapat disimpulkan bahwa kulit kelapa muda menghasilkan asap cair $100 \mathrm{ml}$ dengan karakteristiknya yaitu $\mathrm{pH} 0.596$, viskositas 1.780 CPs dan densitas $0,343 \mathrm{~g} / \mathrm{cm}^{3}$, Bambu menghasilkan asap cair $120 \mathrm{ml}$ dengan karakteristiknya yaitu pH 0.707 , viskositas 2.626 CPs dan nilai kalori $1983,950 \mathrm{Cal} / \mathrm{g}$, densitas $0,427 \mathrm{~g} / \mathrm{cm}^{3}$, dan kulit durian menghasilkan asap cair $74 \mathrm{ml}$ dengan karakteristiknya yaitu $\mathrm{pH} 0.676$, viskositas $1.574 \mathrm{Cps}$ dan nilai kalori $2177,464 \mathrm{Cal} / \mathrm{g}$, densitas $0,271 \mathrm{~g} / \mathrm{cm}^{3}$.

\section{Ucapan Terima Kasih}

Ucapan terima kasih disampaikan kepada Direktorat Riset dan Pengabdian Masyarakat Kementrian Riset Teknologi dan Pendidikan Tinggi Republik Indonesia yang sudah mendukung penelitian ini dalam program Penelitian Strategi Nasional tahun anggaran 2019. Dan tidak lupa pula kepada Rektor Universitas Muhammadiyah Metro serta Ketua Lembaga Penelitian dan Pengabdian kepada Masyarakat Universitas Muhammadiyah Metro.

\section{Referensi}

[1]. Setiawan, Bagus.. 2016, Analisa Thermogravimetry Pada Pirolisis Limbah Pertanian, Jurnal Ethos, Vol. 4 No. 1, ISSN. 1693-699X I EISSN. 2502-065X, Hal. 49-56.

[2]. Yaman, S., 2004, "Pyrolysis of biomass to produce fuels and chemical Feedstocks", Energy Conversion and Management, 45, 651-671.

[3]. Guillen, M.D., dkk. 2001. Carbohydrate and nitrogenated coumpounds in liquid smoke flavoring. $\mathrm{J}$ agric Food Chem 49: 2395-2403.

[4]. Kamulyan, B., 2008, Isolasi Bahan Bakar (Biofuels) dari Tarasap cair hasil pirolisis tempurung kelapa, Tesis, FMIPA, Universitas Gadjah Mada. Sembawa.

[5]. Harinen, S. , 2004, Analysis of The Top Phase Fraction of Wood Pyrolysis Liquids", Master Thesis, Laboratory of Applied Chemistry, Department of Chemistri, University of Jyvaskyla.

[6]. Hatta, V, 2007, Manfaat kulit durian selezat buahnya, Karya Ilmiah, Universitas Lampung, Lampung, diakses 2 Maret 2014, <http://etd.ugm.ac.id>

[7]. Anindyawati, T, 2010, 'Potensi selulase dalam mendegradasi lignoselulosa limbah pertanian untuk pupuk organik', Jurnal Berita Selulosa, vol. 45, no. 2, hal. 70-77, diakses 15 Pebruari 2014.

[8]. Rathod A dan Kolhatkar A. 2012. Handle properties of bamboo and cotton fabric. Di dalam: China Textile Science, Vol. 2, Textech Publishing, 36-40.

[9]. Suparno, Ono,. Danielli, Roberto,. 2017, Penghilangan Hemiselulosa Serat Bambu Secara Enzimatik Untuk Pembuatan Serat Bambu, Jurnal Teknologi Industri Pertanian, Vol. 27 No.1: Hal. 89-95 ISSN. 0216-3160 EISSN 2252-3901.

[10]. Pugersari, Dewi,. Achmad Syarief dkk, 2013, Eksperimen Pengembangan Produk Fungsional Bernilai Komersial Berbahan Baku 
Tempurung Kelapa Berusia Muda dengan Teknik Pelunakan, Jurnal Vis. Art \& Des, Vol. 5, No. 1, ISSN: 1978-3078, DOI: 10.5614/itbj.vad.2013.5.1.5 , Hal. 74-91.

[11]. Kilinc, B., Cakh, S. (2012), Growth of Listeria monocytogenes as affected by thermal treatment of rainbow trout fillets prepared with liquid smoke. Turkish Journal of Fisheries and Aquatic Science, 12, 285290.

[12]. Isamu, K. T., Purnomo, H., Yuwono, S. S. (2012) Physical, chemical, and organoleptic characteristics of smoked skipjack tuna (Katsuwonus pelamis) produced in Kendari-South East Sulawesi. African Journal of Biotechnology 11(91), 1581915822.

[13]. Anggraini S.P.A. dan S. Yuniningsih, 2014, Utilization Of Various Types Of Agricultural Waste Became Liquid Smoke Using Pyrolisis Process, Chemical and Process Engineering Research, 28.

[14]. Ayudiarti, D.L. dan R.N. Sari, 2010, Asap Cair dan Aplikasinya Pada Produk Perikanan, Squalen, $5: 3$.

[15]. Ratnawati,. Hartanto, S., 2010. Pengaruh Suhu Pirolisis Cangkang Sawit Terhadap Kuantitas dan Kualitas Asap Cair. Jurnal Akreditasi LIPI, 2010, 12 (1) : 7-11.

[16]. Yatagai, M., Unrinin, G and T. Ohira. 1988. By-products of wood carbonization, IV. Mokuzai Gakkaishi. 34 (2) : 184 - 188.
Temperatur Dan Ukuran Partikel Biomassa Terhadap Bio-Oil Hasil Pirolisis Ampas Tebu / Baggase, Jurnal Teknoin Vol. 22 No. 5. Hal. 328-336.

[18]. Sunarsih, Sri. , Pratiwi, Yuli, dkk (2012), Pengaruh Suhu, Waktu Dan Kadar Air Pada Pembuatan Asap Cair Dari Limbah Padat Pati Aren (Studi Kasus Pada Sentra Industri Sohun Dukuh Bendo, Daleman, Tulung, Klaten), Prosiding Seminar Nasional Aplikasi Sains \& Teknologi (SNAST) Periode III di Yogyakarta, ISSN: 1979911X 